\title{
Chapter 15 \\ Enhanced Production of Finfish and Large Crustaceans by Bivalve Reefs
}

\author{
Boze Hancock and Philine zu Ermgassen
}

\begin{abstract}
Several bivalve families include species that occur in sufficient densities to modify the environment and create structured biogenic habitat. These habitats have also suffered among the highest losses of any marine habitat globally. In the case of bivalve reefs, the physical structure provided by the shells, supplied with biodeposits produced from filter feeding, supports a high density of macroinvertebrate prey, as well as providing shelter for many juvenile fish. This combination leads to enhanced fish production when compared to the unstructured sediment; the habitat type which typically replaces bivalve reefs when they are destroyed. Measuring the densities of juvenile fish and crustaceans on oyster reefs, and at unstructured control sites provides a measure of the net increase in juvenile fish and large crustaceans supported by oyster habitat. Applying growth and mortality schedules from fishery stock assessment literature allows an estimate of the increased lifetime production of juveniles by oyster reef habitats. Species may also benefit from oyster reefs at later life history stages, but these potential benefits have not been included in the current estimates of production. Services such as increased fish production have been used to highlight the range of stakeholders, in addition to the oyster fishers, that benefit from oyster habitat. The broader constituent base for bivalve habitats includes groups such as recreational anglers and commercial fishers as well as the industries that support them. Engaging with these stakeholders through quantifying the benefits of bivalve habitats to fisheries has proven an invaluable asset in promoting bivalve habitat restoration globally, as well as in drawing more funding into restoration efforts. Furthermore, quantifying fish production introduces the potential to include habitats such as those produced by bivalves in Ecosystem-based Fisheries Management.
\end{abstract}

\footnotetext{
B. Hancock $(\bowtie)$

The Nature Conservancy, URI Graduate School of Oceanography, Narragansett, RI, USA e-mail: bhancock@tnc.org

P. zu Ermgassen

Changing Oceans Group, School of Geosciences, University of Edinburgh, Grant Institute,

Edinburgh, UK

e-mail: Philine.zuermgassen@cantab.net
} 


\begin{abstract}
Chinese 摘要: 当某些双壳贝类家族的个体密度达到一定程度时, 它们可以改变环境并形成结构化的生物栖息地。这类栖息地的消亡也属于全 球性海洋栖息地损失的范畴。双壳贝礁, 通过贝壳形成物理结构, 以摄食活动 产生的生物沉积物作为营养物质来源, 为众多的大型无脊椎动物提供, 并为许 多幼鱼提供栖息场所。与非结构化底质相比, 这种底质环境会促进鱼类产量 提高; 而当这种贝壳礁被破坏时, 栖息地的类型往往也会改变。通过对比测 量牡蚛礁和对照地点的幼鱼和甲壳类动物的密度, 可以衡量牡蚛礁型栖息地 对于幼鱼和大型甲壳类动物净增长的促进作用。应用渔业资源评估文献中的 生长和死亡率时间表, 我们可以估算牡蚛礁类栖息地对延长幼鱼生命周期的 作用。许多物种在生命周期的末期可能会从牡蚛礁中受益。除了收获牡蚛 外, 一些业主也从牡蚛礁栖息地周围的鱼类产量增加而获益。除了养殖户以 及养殖企业, 垂钓爱好者也是从双壳贝礁生态多样性的受益者。通过量化双 壳贝礁对养殖企业的积极作用, 并与企业进行合作是推动全球双壳贝类栖息 地恢复工作的重要渠道和方式。此外, 将鱼类养殖业中的各种因素进行量化 可以更好地阐述牡蚛礁在生态系统水平渔业管理应用中的潜力。
\end{abstract}

Keywords Fish production · Bivalve habitat · Oyster reef · Mussel bed · Ecosystem services $\cdot$ Ecosystem-based fisheries management

关键词 鱼类生产, 双壳栖息地, 告蚛礁, 贻贝床生态系统服务, 基于生态系统 的渔业管理。

\title{
15.1 Bivalves As Ecosystem Engineers Supporting Fish Production
}

Ecosystem engineers are organisms that modulate the availability of resources to other species, by causing physical state changes in biotic or abiotic materials (Jones et al. 1994). In the case of bivalve reefs, ${ }^{1}$ they create and maintain habitat primarily through the deposition of generations of shell (Gutiérrez et al. 2003, Walles et al. 2015), supplemented by a constant supply of biodeposits from filter feeding (Kellogg et al. 2013). The structure created by a matrix of shell provides shelter for many species and the biodeposits, in the form of faeces and pseudofaeces, supply concentrated nutrients to the benthic deposit feeders. It is the combination of shelter and protection from predation, combined with the biodeposits fueling a greater abundance of prey, that has long been considered as driving force for enhanced fish production by bivalve habitat (Humphries et al. 2011, Kesler 2015).

\footnotetext{
${ }^{1}$ A definition of 'reef', and 'biogenic structure' are given in Appendix 1 of the Natura2000 Marine documents at http://ec.europa.eu/environment/nature/natura2000/marine/docs/appendix_1_habitat.pdf.

Bivalve reefs are alternatively referred to as shellfish reefs in many publications.
} 
A range of bivalves fall into the category of ecosystem engineers. The primary groups that generate habitat are the oysters (Ostreidae) along with many species of mussels (Mytilidae). Other groups form aggregations dense enough to be considered as biogenic structure, such as the pearl oysters (Pteriidae), leaf oysters (Isognomonidae), and fan clams or penn shells (Pinnidae) (Gillies et al. 2015). However, relatively few current examples of high density reefs or beds (where the structured habitat has little vertical elevation) exist for these groups. There is also a lack of information on the historic extent of habitat formed by these groups which makes it difficult to determine their historic importance in forming biogenic structure.

Oysters and mussels are recognized worldwide as generating dense beds or reefs that may develop to a depth of many meters (Büttger et al. 2008, Todorova et al. 2009). As such they are the estuarine and higher latitude analogs of coral reefs, often consisting of substantial calcium carbonate structures with an outer veneer of living bivalves (Stenzel 1971, Walles et al. 2015). Bivalve habitats also support a generally diverse and dense array of associated organisms (Harding and Mann 2001). Although there is strong anecdotal evidence that mussel habitat is important for fish production, there are currently no quantitative measures of this impact. Restoration of mussel bed habitat is currently being undertaken on an experimental scale in Port Phillip Bay Australia (Mytilus edulis), and in the Haruki Gulf of New Zealand (Perna canicularis), along with the penn shell (Atrina zelandica), with the aim of improving water quality and for the production of fish, in particular pink snapper (Pagrus auratus), a popular recreational species (www. http://reviveourgulf.org.nz/). Similarly, the fishing community of El Manglito near La Paz, Mexico have traditionally lived from fishing in the Ensenada and La Paz Bay. This community has linked the functional extinction of the pen shell habitat in the Ensenada de La Paz with the collapse of the finfish stocks in this once productive bay, and are planning the restoration of the pen shell habitat as a recovery strategy for the finfish fishery (B. Hancock, personal communication).

Oyster reefs are the best understood of the biogenic bivalve habitats. They have suffered the greatest losses of any marine habitat that has been examined (Beck et al. 2011) with more than 90\% loss in many areas (Beck et al. 2011; zu Ermgassen et al. 2012; Alleway and Connell 2015; Gillies et al. 2015). As in the case with the examples from mussel habitat in New Zealand and the Pinnidae shell habitat in New Zealand and Ensenada de La Paz, Mexico, oyster reefs have long been assumed to be important habitats for fish production (Fig. 15.1). The motivation to quantify fish production has been driven by this understanding of the links between healthy bivalve habitats and fish production, and the potential value of this ecosystem service in supporting the restoration of oyster habitat. 

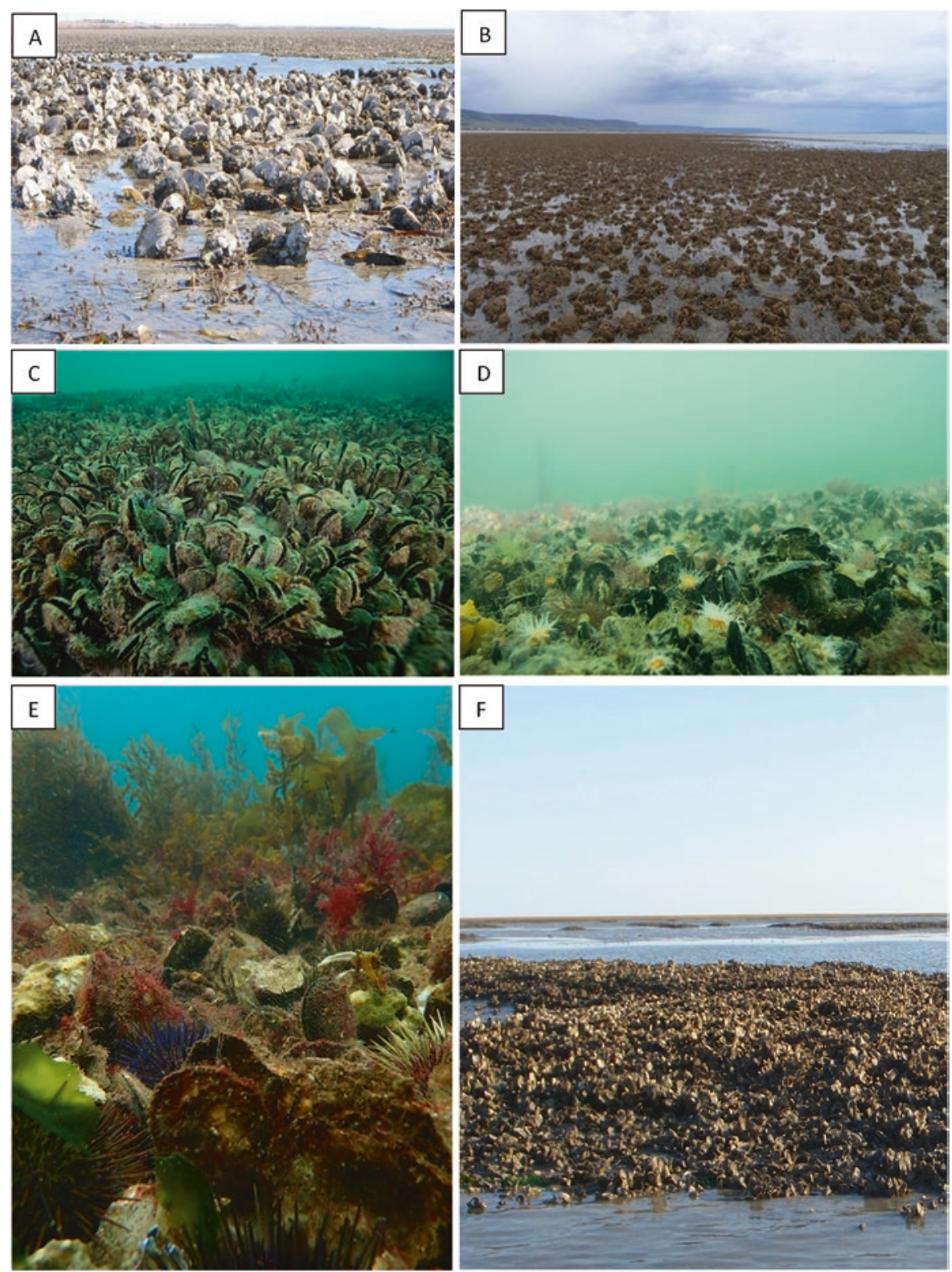

Fig. 15.1 Examples of bivalve reefs that form structured habitat. (a) Pinna bicolor in Streaky Bay, South Australia (Peter Hunt). (b) Pearl Oysters Pinctada albina in upper Spencer Gulf South Australia (Heidi Alleway) (c) Restored Green Lipped Mussel Bed Perna canaliculus in the Hauraki Gulf New Zealand (Richard Robinson) (d) Restored mussel bed Mytilus edulis in Port Phillip Bay, Victoria, Australia (Simon Branigan) (e) Oyster reef Ostrea angasi in Georges Bay, Tasmania, Australia (Chris Gillies) and (f) Restored oyster reef Crassostrea virginica in Virginia, USA (Bo Lusk) 


\subsection{History of Quantifying Fish Production from Oyster Habitat}

Oysters have long been fished by coastal communities (Rick and Erlandson 2009). Since the first century AD the Romans imported oysters from as far afield as southern England (Philpots 1890). The rise of mechanised fishing led to the global collapse of oyster stocks (Beck et al. 2011). Consequently, oyster restoration efforts have long been part of the wild oyster fishery in many parts of the world (SavilleKent 1894; Ogburn et al. 2007). It is, however, only recently that work in the United States paved the way for oyster habitat restoration for the multiple services provided by this habitat, in addition to the oyster fishery (e.g. enhanced water quality and shoreline protection; Petersen et al. 2019; Ysebaert et al. 2019). This is a conservation action that has gained a high level of support as the ecosystem service benefits that oyster habitats provide have become better understood.

One compelling service is the increased production of finfish and large crustaceans. Much of the early thinking behind quantifying the fish production from oyster habitat came from Federal Government mandates in the United States. One initial driver of oyster habitat restoration was a government-legislated requirement to restore the public resources injured by discrete environmental incidents such as chemical or oil spills, the release of pollutants from an identifiable catastrophic event, or from physical damage to the habitat such as dredging for port expansion or land reclamation (e.g. NOAA 1977). The initial legislation was described in the Comprehensive Environmental Response, Cleanup and Liability Act (CERCLA 1980) and the Oil Pollution Act (OPA 1990). For each incident addressed under such legislation the damage first needed to be quantified, prior to designing restoration to make the community 'whole'. These laws helped develop both the practice of oyster habitat restoration and the initial methods to measure fish production from oyster habitat as an additional service to be accounted for. The acts dictate that restoration is undertaken to compensate the public for losses or injuries to natural resources under public ownership and held in trust by government managers and that restoration includes the services that those natural resources would have provided. This legislation continues to influence the quantification of ecosystem services from multiple habitats, including bivalve habitat, and is being expanded in the US section of the Gulf of Mexico through the Restore Act (2012), legislating the response to the Deep Water Horizon oil spill (available at https://www.treasury.gov/ services/restore-act/Pages/home.aspx).

A parallel driver of oyster habitat restoration stems from the conservation communities interest in restoring this previously abundant and ecologically significant habitat. While the increasing number of comprehensive studies documenting and quantifying the loss of oyster habitat are essential for setting a realistic order of magnitude for the amount of habitat that might be restored (Beck et al. 2011; zu Ermgassen et al. 2012, 2013; Alleway and Connell 2015; Gillies et al. 2015), simply 
understanding the loss does not, by itself, generate the incentive to fund and support restoration at the required scale. Given the expense and time required for successful restoration, it has become increasingly necessary to quantify the services provided by the restored oyster habitat in order to place a monetary value on those services and demonstrate the tangible gain society receives from their restoration. Quantifying the expected tonnage of fish and large crustaceans produced per unit area of restored oyster reef has been a powerful way to demonstrate the value of oyster habitat to society and the return on the investment in oyster habitat restoration (C. Gillies, TNC, personal communication).

An additional motivation to quantify the fish production from marine habitats was the concept of Essential Fish Habitat (EFH) which was introduced to fishery management in many jurisdictions from the mid 1980s (e.g. Minns et al. 2011) and in the US in 1996 through the Magnusson-Stephenson Fishery Conservation and Management Act. The Act linked fish production to habitat, attempting to expand the focus of fishery management to include consideration of the capacity of the ecosystem to produce fish, rather than focusing purely on limiting extraction from stocks of the target species (Pikitch et al. 2004). The legislation also had the effect of focusing attention on how to measure the impact of habitat on fish production (Peterson et al. 2000). The concept of certain habitats being limited but important to one or more life history stages and, therefore, the overall success of a fish population, is among the most fundamental questions in fisheries ecology, and the foundation of the concept of EFH. When applied to the early life history stages, generally referred to as juvenile fish habitat, it recognizes that the early life history stages are typically those with the highest mortality rates and where small changes in survival can have large impacts on the number of individuals surviving to older cohorts.

The changes in habitat dependence of different age classes of many fish and large crustaceans complicates the measurement of the relative values of fish production by habitat for these species. A complete accounting of fish production would require assessing the contribution of habitat to fish production by individual age classes of fish. One alternative is to focus on one year class, simplifying the investigation to a level that can be measured and applied (e.g. Levin and Stunz 2005). The 0+ year class is the most abundant and also usually subject to the highest rates of mortality. Consequently, nursery habitats that impact the survival of this cohort will have the greatest influence on the lifetime production.

The work of Peterson et al. (2003) has been influential in the development of methods for modelling the fish production from oyster habitat. zu Emgassen et al. (2016a) have conducted one of the first meta-analyses of the degree to which oyster habitat enhances the density of young-of-year fish and macro-invertebrates, and the consequent increase in production of those species over their lifetime. This has made oyster reefs a model system for quantifying the magnitude and regional variability in augmented fish production from nursery habitats (Fig. 15.2). 

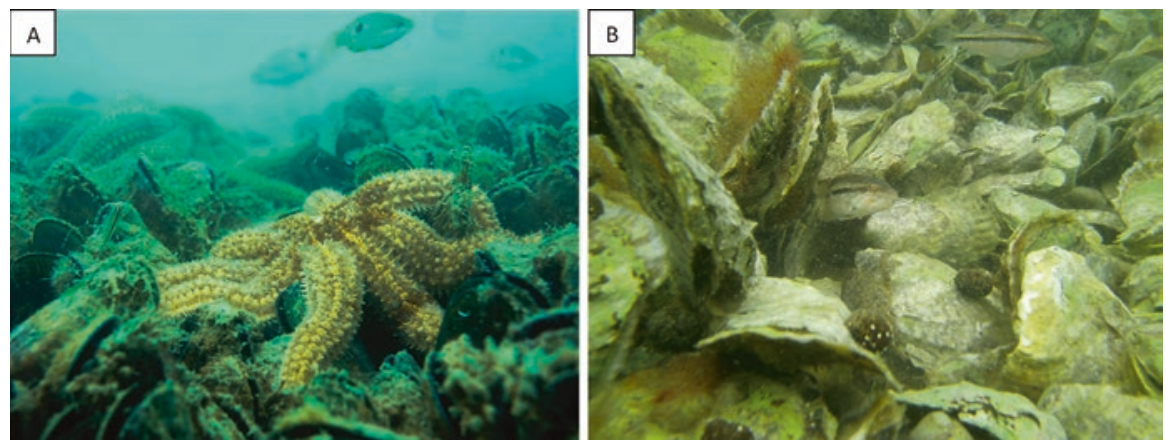

Fig. 15.2 Fish and invertebrates utilizing restored (a) Mussel bed Perna canaliculus in Hauraki Gulf, New Zealand (Shane Kelly) and (b) Crassostrea virginica oyster reef Rhode Island USA (Matt Griffin)

\subsection{Current Status of Quantifying Fish Production Enhancement by Oyster Habitat}

Quantitative data on the degree to which fish and macroinvertebrates are enhanced by bivalve habitats are rare outside of the United States. While there has been recent progress in understanding the role of Modiolus modiolus in Europe as an important habitat for the commercially important whelk Buccinum undatum (Kent et al. 2016, 2017), for most bivalve habitats outside of the U.S. evidence is limited to historical documentation of species counts (e.g. Moebius 1883; Riesen and Reise 1982). In order to quantify the enhancement of fish and invertebrate production by bivalve habitats, it is necessary to measure the abundance of the target age classes within the habitat, relative to where that habitat is absent. As such, repeated and paired density data from the contrasting habitats are essential in supporting such quantification.

By collating available paired on and off oyster reef fish and invertebrate data from 31 studies in the United States, zu Ermgassen et al. (2016a) identified species for which the juveniles were consistently found at higher abundances on oyster habitats as opposed to unstructured mud and sand habitat. These habitats often replace oyster reefs when lost, and were therefore considered the most suitable control habitat for comparison. As in Peterson et al. (2003), the authors found that the presence of oyster reef enhanced species at both the juvenile and later life history stages. They also found marked differences between biogeographical regions with regards to the species of fish and invertebrates enhanced by oyster reefs, with 12 species in the Mid and South Atlantic and to 19 species in the Gulf of Mexico enhanced as juveniles, and two and five species respectively at later life history stages.

By applying established growth and mortality estimates to the enhanced densities of juveniles found on as opposed to off oyster reefs, zu Ermgassen et al. (2016a) estimated the year on year production of each of the consistently enhanced species (Fig. 15.3). This represents the increased production resulting from the presence of oyster reef habitat as opposed to unstructured benthic habitats. Enhancement can 

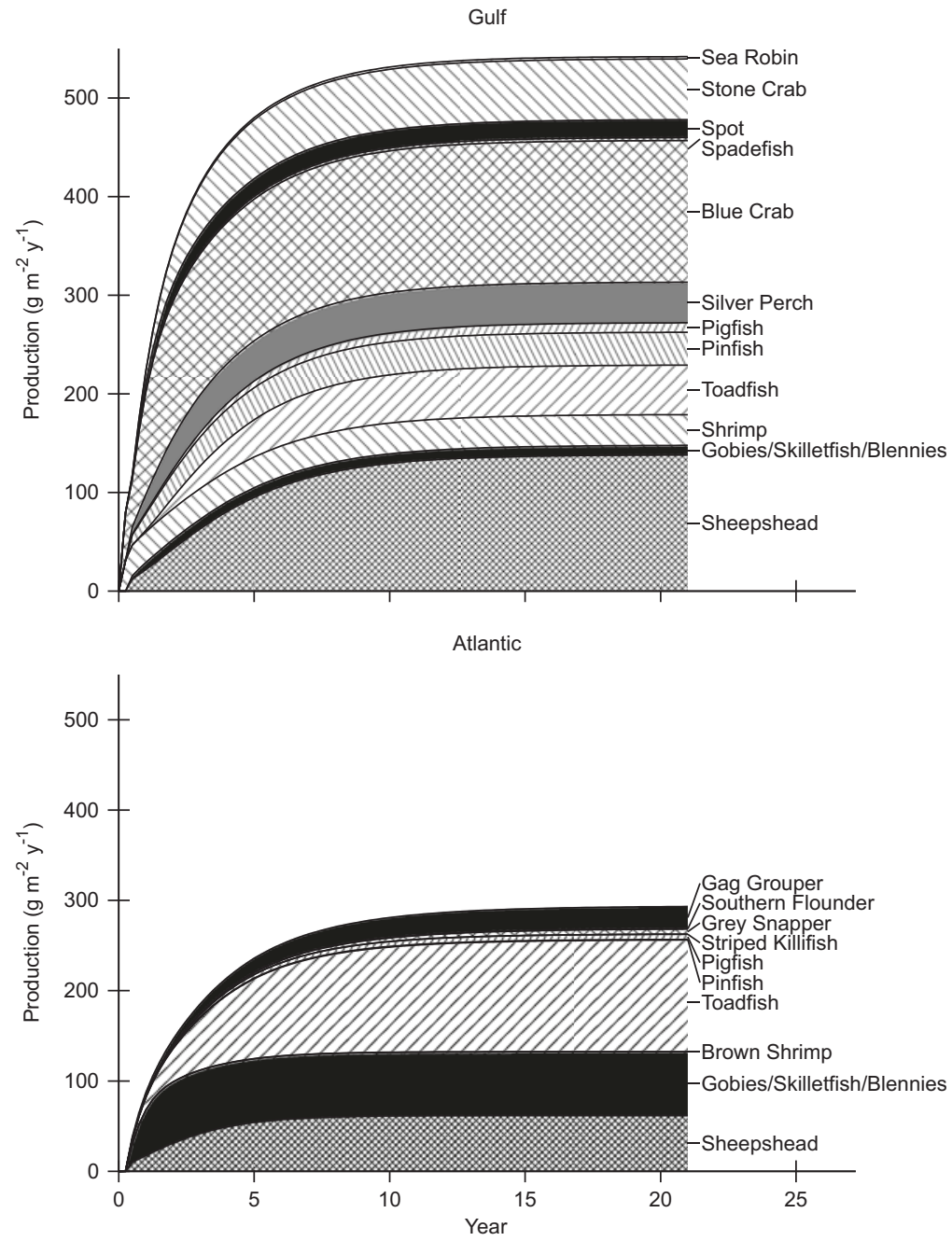

Fig. 15.3 Graphs of the annual enhancement in production per species resulting from the presence of oyster reef as opposed to unstructured benthic habitat for the Gulf of Mexico and the US Atlantic south of Cape Cod. Enhancement can be considered as annual post-restoration enhancement up to the asymptote, which represents the annual enhancement seen at existing natural reefs. The recreationally and commercially important species include stone crab, spot, spadefish, blue crab, silver perch, pigfish, shrimp, sheepshead, gag grouper, southern flounder and grey snapper, with sea robin and toad fish being targeted by a smaller but increasing number of fishers (zu Ermgassen et al. 2016a, updated in zu Ermgassen et al. 2018)

represent either production post-restoration; in which case the production value increases over time as successive generations and years of growth which can be attributed to the oyster habitats accumulate (Fig. 15.3), or existing oyster habitats (the value illustrated at the end of the graph can be attributed year on year). The 
error distribution was also calibrated to the variance obtained from the original publications. They found that each ha of oyster reef provided on average an additional $2.83 \pm 0.57 \mathrm{t} /$ year in the South and Mid-Atlantic and 5.28 $\pm 1.28 \mathrm{t} /$ year in the Gulf of Mexico (Fig. 15.3). These estimates currently stand as the most developed estimates of the fisheries ecosystem service potential of oyster reef habitats. Of these species enhanced as juveniles, many of them are of direct fisheries value, with others representing forage fish and prey for the higher trophic fisheries species (Fig. 15.3). Only the contribution of the species directly benefiting from oyster reef as a juvenile nursery ground are fully quantified in this approach. The contribution of enhanced growth in later life history stages was not tackled, due to a concern regarding double counting of benefits and the ongoing attraction versus production debate surrounding the role of structured habitats for later life history stages (e.g. Pierson and Eggleston 2014). The full ecosystem service value from the enhancement by oyster reefs on fisheries is therefore challenging to quantify, as the total value will be a sum of the quantified juvenile enhancement of fisheries species, the contribution of the enhanced abundance and biomass of prey species consumed once they leave the reef, and the contribution of the enhanced prey items available on the reef for species that associate with the reef at later life history stages. Peterson et al. (2003) attempted to assess this value, but it is generally agreed that more detailed habitat specific life history information would greatly improve the existing estimates. Despite the current model providing a conservative estimate of the augmented fish production from the increased abundance of only one year class it is, none the less, substantial and does provide a measure of fish production on a regional scale that is relevant to policy and management. The model also provides valuable estimates of the uncertainty surrounding the model predictions (Fig. 15.4).

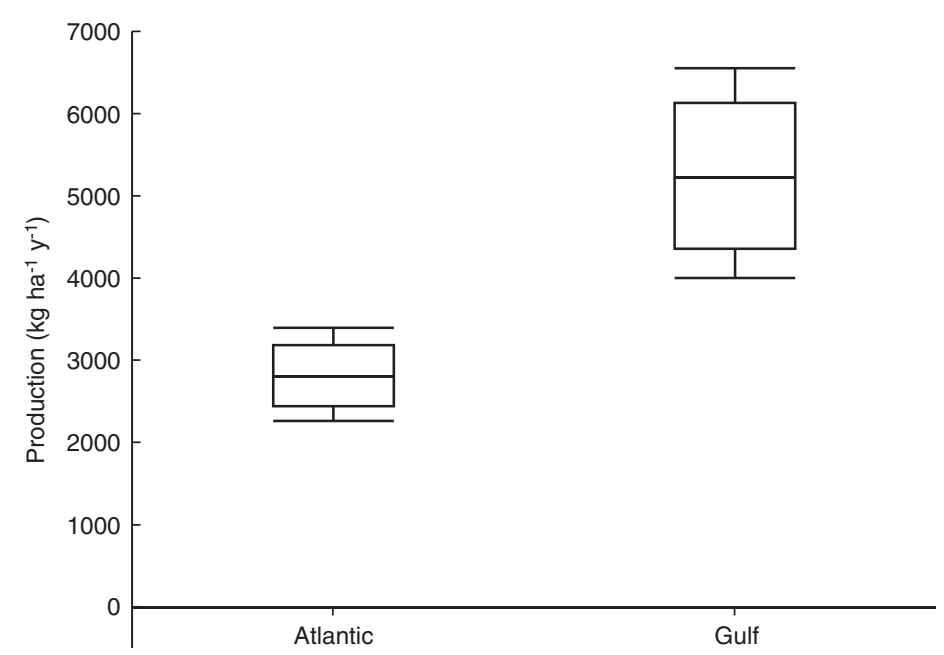

Fig. 15.4 Mean, upper and lower quartile and minimum and maximum estimated enhancement of gross production of fish and large crustacean resulting from the presence of oyster reef as opposed to unstructured benthic habitat in both the Gulf of Mexico and the Mid and South Atlantic region of the USA at $t_{\max }$ of the longest-lived species (zu Ermgassen et al. 2016a) 
Table 15.1 Species found by zu Ermgassen et al. (2016a) to derive growth enhancement from $C$. virginica oyster reef in the Gulf of Mexico and in the South and Mid-Atlantic (zu Ermgassen 2016a)

\begin{tabular}{l|l|l|l}
\hline & Species & Common name & $\begin{array}{l}\text { Proportion of individuals caught on } \\
\text { oyster reefs (\%) }\end{array}$ \\
\hline \multirow{2}{*}{$\begin{array}{l}\text { Gulf of } \\
\text { Mexico }\end{array}$} & $\begin{array}{l}\text { Menticirrhus } \\
\text { americanus }\end{array}$ & Southern kingfish & 52 \\
\cline { 2 - 4 } & $\begin{array}{l}\text { Paralichthys } \\
\text { lethostigma }\end{array}$ & Southern flounder & 82 \\
\cline { 2 - 4 } & Pogonias cromis & Black drum & 75 \\
\cline { 2 - 4 } & Rhinoptera bonasus & Cownose ray & 82 \\
\cline { 2 - 4 } & Sciaenops ocellatus & Red drum & 63 \\
\hline \multirow{2}{*}{$\begin{array}{l}\text { Atlantic } \\
\text { coast }\end{array}$} & Centropristis striata & Black Sea bass & 63 \\
\cline { 2 - 4 } & Morone saxatilis & Striped bass & 93 \\
\hline
\end{tabular}

The potential importance of oyster reef habitats to species which utilize the habitat at later life history stages can be inferred by calculating the relative amount of time spent within each habitat. While fish may be caught in areas through which they seek to migrate quickly, rather than where they are spending the majority of their time, there is ample evidence of many large species choosing to spend more time over oyster reefs as they are rich foraging ground (e.g. Harding and Mann 2003; George 2007). zu Ermgassen et al. (2016a) therefore calculated the proportion of time spent over oyster reef, or the proportion of adult individuals caught over oyster reef as opposed to neighboring unstructured habitats in order to assess which species oyster reef may be important for at later life history stages. They found that five species from the Gulf of Mexico and two species from the Atlantic coast of the US that spent a large proportion of their time on oyster reefs: between 52\% (Southern kingfish, Menticirrhus americanus) and 93\% (Striped bass, Morone saxatilis) (Table 15.1). These species are believed to derive some degree of growth enhancement from the oyster habitat, from feeding disproportionately frequently on oyster reefs.

\subsection{Assumptions and Limitations of the Current Approach}

The approach developed initially by Peterson et al. (2003) and further developed by zu Ermgassen et al. (2016a) has provided a novel opportunity to gauge the lifetime benefits of nursery habitats to fish and invertebrate populations. The benefits that can be attributed to nursery habitats from reduced juvenile mortality are substantial and otherwise extremely challenging to capture. The approach is, however, dependent on the application of established fish growth and mortality models used in fishery stock assessment and as such should be caveated by the same underlying assumptions. Estimates of fish and invertebrate growth were derived by applying the von Bertalanffy growth curve to juveniles. In order to do so, various life history 
traits need to be known. These traits (length at infinite age, the constant K, and the length at time equals zero) are themselves estimated and may therefore be subject to some error. Estimated natural mortality is also required for the model. Mortality is one of the greatest sources of uncertainty in fisheries models (Rosenberg and Restrepo 1994), especially at smaller size classes as mortality derived from the field is often reliant on fisheries size classes. In order to reduce, as far as possible, the uncertainty in the mortality estimates applied, zu Ermgassen et al. (2016a) used the size dependent mortality equation developed by Lorenzen (2000), so as to better represent the higher mortality suffered by the small size classes of fish and invertebrates represented in the model.

It is universally known that any model is only as good as the data it uses. While oyster reefs in the U.S. are the best studied in the world, zu Ermgassen et al. (2016a) point out that some of the differences in fish and invertebrate enhancement between regions are still likely due to a lack of data and differing sampling efforts or techniques between regions. As such, the inclusion of more data in the model can only serve to improve the resulting estimates of the benefits of oyster reefs as nursery habitats. The data handling approach used required that species were represented in at least two different estuaries in order for that species to be included in the assessment. It is therefore possible that some rarer species, or species which are not as effectively captured using density-specific capture techniques (e.g. drop traps, seines), are currently missing from the existing estimates. A larger number of studies seeking to quantify the enhancement of the fish and invertebrate community by oyster reefs can only serve to improve the current model.

One important assumption of the model that is highlighted in zu Ermgassen et al. (2016a) is that the bivalve habitat must be limiting in the site of interest. The model provides an estimate of the per unit area enhancement of the fish and invertebrate community by oyster reef habitats. The authors argue that in the current landscape of extreme loss of oyster and other bivalve habitats globally it is likely that, for species whose juveniles are enhanced by oyster reef presence, habitat is in fact limiting. As such the addition of habitat should result in a greater number of individuals surviving to larger size classes. The authors, however, concede that should substantial areas of oyster reef be restored, other factors may well start to limit the production and the assumed linear relationship between habitat area and juvenile enhancement would cease to exist. The point at which this would happen is likely to be highly species dependent and the position of any such threshold, or even how to derive it, remains unknown. As such, it is important to bear this assumption in mind when planning large scale restoration or recovery of oyster habitats, so as not to oversell the potential of oyster reef in supporting fisheries as an ecosystem service in these later stages of oyster habitat recovery.

A further consideration is the effect of habitat redundancy, or the interaction between structured habitats in close proximity, on the nursery function of oyster reefs. Oyster reefs close to alternative structured habitats, such as seagrasses and saltmarshes may not result in the same, or indeed any, observable enhancement of juvenile fish (Grabowski et al. 2005; Geraldi et al. 2009), most likely because the abundance of an equivalent structured habitat can provide similar food and shelter 
to oyster reefs. This is, however, certainly not always the case, with some studies finding that oyster reefs in seagrass and saltmarsh landscapes enhanced invertebrate (Grabowski et al. 2005) and fish (Stunz et al. 2010) communities. An assessment of the interaction between the different types of essential fish habitat, when they occur in close proximity, will be important for fine tuning the overall estimates of fish production from structured habitat on an estuary scale.

\subsection{Making the Results Available}

Among the primary motivators for quantifying the production of fish and large crustaceans from bivalve habitat is the need to quantify the services lost (and therefore the services to be restored), following an environmental disaster like an oil spill, and also to help regulators and funders within the conservation community visualise the benefit from restoration. The ability to easily visualise the return on a restoration investment in terms of the fish produced, by species, helps the many stakeholder groups formally involved in habitat restoration, set meaningful goals for restoration on a bay or estuary scale. While the quantity of fish produced from a given restoration scenario can be calculated from the data provided (zu Ermgassen et al. 2016a) or estimated from the graphs in Fig. 15.3, providing a tool that allows this benefit to be immediately calculated for any proposed restoration could benefit those conversations. To facilitate this outcome a coalition of partners has produced a manual describing the multiple services derived from oyster habitat (zu Ermgassen 2016b). Of these services, the filtration (Cranford 2019) and fish production services have been quantified sufficiently accurately to be included in a 'Web Calculator' for the USA (Fig. 15.5, the calculator is available at http://oceanwealth. org/tools/oyster-calculator/). At present estimates of enhanced fish production are available for the US Gulf of Mexico and the US South and mid-Atlantic coasts as described above, and filtration results are available for the US east, gulf and Pacific coasts. The area included in the calculator will be expanded as the relevant filtration algorithms and fish production data become available. As additional data will likely allow fine tuning of the results the calculator and associated manual (zu Ermgassen 2016b) may be updated and the web site should be accessed for the most recent results. Additional services such as denitrification rates (Ferreira and Bricker 2019) will also be added when their quantification is sufficiently understood to be represented at a regional scale.

The calculator is designed to allow users to enter data such as existing oyster density and mean size, expected oyster density and mean size for the restored habitat, and adjust the target $\%$ of the estuary volume to be filtered by oysters within the residence time of the estuary (see also Smaal and van Duren 2019). Existing data such as estuary volume, the residence time of water within the estuary, mean summer water temperature, and the historic percentage of estuary filtration achieved by the biomass of oysters present at the earliest available census (generally around 1900), and even recent existing oyster size and density values, are provided where available. The site calculates the area of oyster habitat that would need to be restored 
A

\section{Matagorda Bay, TX}

To use the calculator, first select a bay location from our database. If using your own site, select the closest site within our database to load oyster mass formula and fish benefits data.

\section{Select site Reset data}

\section{BAY PROPERTIES ?}

\begin{tabular}{|l|l|}
\hline Bay Volume & \\
\hline 1572150 & $1000 \mathrm{~m}^{3}$ \\
\hline Temperature & \\
\hline 30.73 & ${ }^{\circ} \mathrm{C}$ \\
\hline
\end{tabular}

\section{CURRENT OYSTER PROPERTIES O}

\begin{tabular}{|c|c|c|c|c|}
\hline \multicolumn{2}{|c|}{$\begin{array}{l}\text { Mean Oyster Length } \\
(<76 \mathrm{~mm})\end{array}$} & \multicolumn{3}{|c|}{$\begin{array}{l}\text { Mean Oyster Length } \\
(276 \mathrm{~mm})\end{array}$} \\
\hline 45.0 & $\mathrm{~mm}$ & 94.1 & & $\mathrm{~mm}$ \\
\hline \multicolumn{2}{|c|}{$\begin{array}{l}\text { Mean Oyster Density } \\
(<76 \mathrm{~mm})\end{array}$} & \multicolumn{3}{|c|}{$\begin{array}{l}\text { Mean Oyster Density } \\
(\geq 76 \mathrm{~mm})\end{array}$} \\
\hline 4.23 & ind $/ m^{2}$ & 0.97 & & ind $/ \mathrm{m}^{2}$ \\
\hline \multicolumn{5}{|c|}{ GOALS 3} \\
\hline \multicolumn{5}{|c|}{ Estuary Filtration Percent } \\
\hline $1 \quad 1$ & 1 & 1 & 50 & $\%$ \\
\hline \multicolumn{2}{|c|}{$\begin{array}{l}\text { Mean Oyster Length } \\
(<76 \mathrm{~mm})\end{array}$} & \multicolumn{3}{|c|}{$\begin{array}{l}\text { Mean Oyster Length } \\
(\geq 76 \mathrm{~mm})\end{array}$} \\
\hline 35.2 & $\mathrm{~mm}$ & 82 & & $\mathrm{~mm}$ \\
\hline \multicolumn{2}{|c|}{$\begin{array}{l}\text { Mean Oyster Density } \\
(<76 \mathrm{~mm})\end{array}$} & \multicolumn{3}{|c|}{$\begin{array}{l}\text { Mean Oyster Density } \\
(\geq 76 \mathrm{~mm})\end{array}$} \\
\hline 120 & ind $/ m^{2}$ & 1.8 & & ind $/ m^{2}$ \\
\hline
\end{tabular}

An estimated $29 \%$ of the bay is currently filtered by oysters. To increase the filtration of the bay to $50 \%$ will require 199 ha ( $492 \mathrm{ac}$ ) of restored habitat. This restored habitat could support $30.6 \mathrm{M}$ young of the year fish per year, which will contribute an estimated $1.1 \mathrm{M}$ $\mathbf{k g}$ biomass over their lifetime.

\section{Filtration Fish Production}

\section{ESTUARY FILTRATION O}

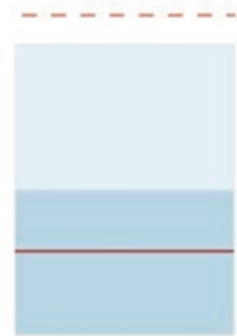

Estuary filter volume $1.7 \mathrm{BL} / \mathrm{h}$

| Historic filtration 87.2 BL/h (5056\%)

ICurrent filtration $498.7 \mathrm{MLh}(29 \%)$

Goal filtration $861.9 \mathrm{ML} / \mathrm{h}(50 \%)$

Goal data, including estuary filtration goals and fish production, is not shown until at least one goal oyster length and density is entered. All calculations are estimates only, based on an extensive literature review.

\section{Ecoregion}

Northern Gulf of Mexico

Oyster mass to Length formula

BeseresPollack et al 2011 for Aransas Bay

(length/10^1.846) $(1 / 0.258)$

Fig. 15.5 Screen capture of the 'Oyster Calculator' Illustrating pre-loaded data for Matagorda Bay, Texas, with hypothetical data in the 'Goals' section and the 'Estuary Filtration Percent' set to $50 \%$. The output tab for 'Filtration' in X5, (a) would normally toggle in the same position as the 'Fish Production' tab in X5, (b) with only one output tab visible at a time. Only a portion of the fish production data are shown in $\mathrm{X} 5$, (b)

to achieve the specified level of filtration and the number and weight of fish, by species, that would be produced from that area of restored oyster habitat. Making these results available in real time during planning conversations is intended to facilitate setting objectives for oyster habitat restoration based on the filtration and fish production services returned at a system scale.

The model results provided in the calculator represent the mean production across the whole of a region. It is therefore critical that local knowledge be used to 


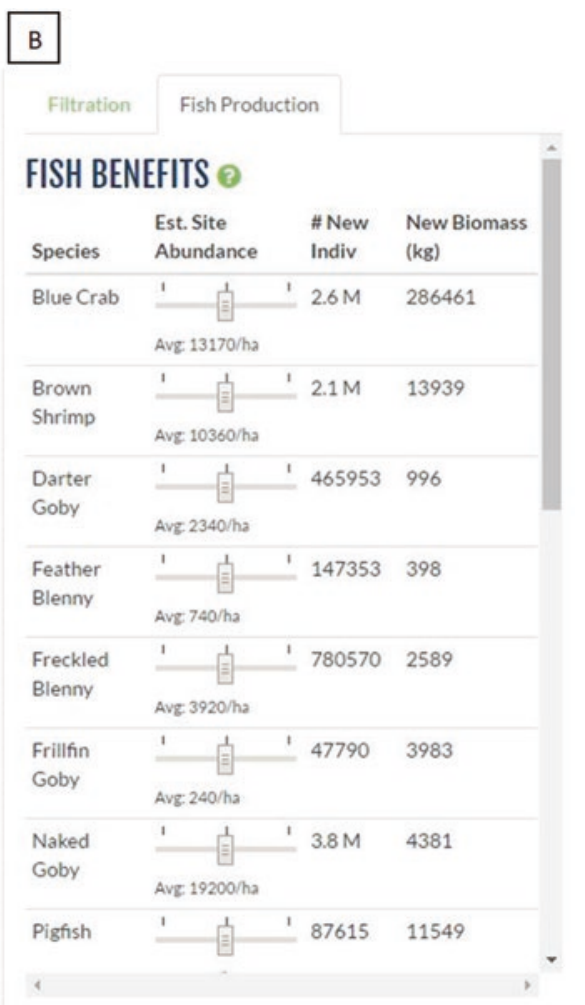

Fig. 15.5 (continued)

adapt the results to more accurately reflect the estimated production at a given site of interest. There are likely to be local factors that affect the availability of one or more species within the suite of species identified as being enhanced by oyster habitat (Humphries and La Peyre 2015). The ability to account for these local variations in species abundance has therefore been built into the calculator. There are options to set the production for any species to zero if the species is deemed absent from the site or rare. There is the option to use the average production from the meta-analysis, or even the upper confidence interval if there is evidence that a species is particularly abundant in the estuary being considered.

\subsection{Management Applications}

The major threat responsible for the reduction of bivalve habitat globally has been overharvest. In fact, the estimated $85 \%$ reduction in oyster habitat over the last approximately 100 years (Beck et al. 2011) is itself an underestimate, as most of the historical surveys undertaken around the end of the 1800s or early 1900s, and used as a baseline measure of the historical extent of oyster habitat, were conducted because of concerns that overfishing had already depleted the oyster stocks (zu 
Ermgassen et al. 2012, 2016b). Much of the subsequent depletion of these habitats has occurred because managers of the fisheries have been responding to the inputs and concerns of only one stakeholder group interested in the habitat; the bivalve fishers. Managers, or the politicians they advise, have therefore been focused solely on the landings of bivalves rather than considering those landings as just one of a number of legitimate services to be considered when managing the bivalve resource. Recognizing that the recreational and commercial fishers, that benefit from the fish and crustaceans produced by the oyster habitat, are also stakeholders with a legitimate interest in the bivalve habitat, along with members of the associated fish processing and recreational support industries, has the potential to change the view of managers responsible for that resource. The same can be said for the constituents connected to the other services provided by bivalve habitats described in this book, such as water quality from filtration and denitrification or increased coastal resilience from shoreline protection (Brumbaugh et al. 2010; Ferreira and Bricker 2019). Similarly, managing oyster resources for harvest alone has tended to focus the emphasis on replenishment activities or put-and-take management intended to increase the supply of oysters for harvest or the amount of shell substrate available for the recruitment of juvenile oysters and their subsequent harvest. This does not consider that oyster biomass and the condition of the oyster reef may be important factors influencing the provision of additional services as well as the long-term sustainability of the restored reef (Grabowski et al. 2012). Demonstrating the value of the finfish and crustaceans produced from oyster habitat is a powerful tool for supporting the protection of at least a portion of the remaining bivalve habitat and investing in the restoration of additional habitat.

Having estimates of the fish production from oyster habitat well documented and available, if only for a small region given the global distribution of biogenic bivalve habitats, provides the ability to influence fisheries management in two important ways. It provides the logic for fundamentally changing the paradigm for managing the fishery, based on consideration of the multiple stakeholder groups impacted by changes in the level of services provided by bivalve habitats, in addition to harvest. It also introduces the option of including bivalve habitat in the management considerations for the finfish and large crustacean species supported by those habitats, in a truly Ecosystem Based Fishery Management (EBFM) scenario.

Ecosystem based fisheries management has been a goal for many fisheries managers for many years and has been adopted to various extents by most fisheries management agencies worldwide (e.g. Fletcher et al. 2010). Most management agencies also recognize that there is still a long way to go, in order to approach comprehensive EBFM (Berkes 2012). Developing habitat specific fish production measures for oyster habitat has generated interest in developing similar measures for multiple essential fish habitats. Analogous measures are currently available from seagrass in southern Australia (Blandon and zu Ermgassen 2014) and shrimp from seagrass in Queensland, Australia (Watson et al. 1993). The development of models to estimate the fish and large crustacean production are currently underway for salt marsh and seagrass habitats from the US and from mangrove habitat globally (Hancock and zu Ermgassen, personal communication). The US studies of fish production from salt marsh and seagrass habitats include provision for engaging the 
fisheries management community in considering how measures of fish production from habitat can be included in fisheries management decisions (NOAA, National Marine Fisheries Service, personal communication), a potentially productive direction for the development of EBFM.

Acknowledgements The authors are grateful to Dr. B. Walles and an anonymous reviewer for their constructive comments on the manuscript.

\section{References}

Alleway HK, Connell SD (2015) Loss of an ecological baseline through the eradication of oyster reefs from coastal ecosystems and human memory. Conserv Biol 29(3):795-804. https://doi. org/10.1111/cobi.12452

Beck MW, Brumbaugh RD, Airoldi L, Caranza A, Coen LD, Crawford C, Defeo O, Edgar GJ, Hancock B, Kay M, Lenihan H, Luckenbach MW, Toropova CL, Zhang G (2011) Oyster reefs at risk and recommendations for conservation, restoration and management. Bioscience 61(2): 107-116

Berkes E (2012) Implementing ecosystem-based management: evolution or revolution? Fish Fish 13:465-476

Blandon A, zu Ermgassen PSE (2014) Quantitative estimate of commercial fish enhancement by seagrass habitat in southern Australia. Estuar Coast Shelf Sci 141:1-8

Brumbaugh RD, Beck MW, Hancock B, Wrona-Meadows A, Spalding M, zu Ermgassen P (2010) Changing a management paradigm and rescuing a globally imperiled habitat. National Wetlands Newsletter, November-December, pp 16-20

Büttger H, Asmus H, Asmus R, Buschbaum C, Dittmann S, Nehls Helgol G (2008) Community dynamics of intertidal soft-bottom mussel beds over two decades. Mark Res 62:23-36. https:// doi.org/10.1007/s10152-007-0099-y

CERCLA (1980) Comprehensive environmental response, cleanup and liability act, Available at https://www.gpo.gov/fdsys/pkg/USCODE-2011-title42/html/USCODE-2011title42-chap103.htm

Cranford P (2019) Magnitude and extent of water clarification services provided by bivalve suspension feeding. In: Smaal A, Ferreira JG, Grant J, Petersen JK, Strand O (eds) Goods and services of marine bivalves. Springer, Cham, pp 119-141

Ferreira J, Bricker S (2019) Assessment of nutrient trading services from bivalve farming. In: Smaal A, Ferreira JG, Grant J, Petersen JK, Strand O (eds) Goods and services of marine bivalves. Springer, Cham, pp 551-584

Fletcher WJ, Shaw J, Metcalf SJ, Gaughan DJ (2010) An ecosystem based fisheries management framework: the efficient, regional-level planning tool for management agencies. Mar Policy 34(6):1226-1238

George GJ (2007) Acoustic tagging of black drum on Louisiana oyster reefs: movements, site fidelity, and habitat use. Master of Science, Louisiana State University and Agricultural and Mechanical College, $71 \mathrm{pp}$

Geraldi NR, Powers SP, Heck KL, Cebrian J (2009) Can habitat restoration be redundant? Response of mobile fishes and crustaceans to oyster reef restoration in marsh tidal creeks. Mar Ecol Prog Ser 389:171-180

Gillies CL, Creighton C, McLeod IM (eds) (2015) Bivalve reef habitats: a synopsis to underpin the repair and conservation of Australia's environment, social and economically important bays and estuaries. Centre for Tropical Water and Aquatic Ecosystem Research (TropWATER) Publication, James Cook University, Townsville, $90 \mathrm{pp}$

Grabowski JH, Hughes AR, Kimbro DL, Dolan MA (2005) How habitat setting influences restored oyster reef communities. Ecology 86(7):1926-1935 
Grabowski JH, Brumbaugh RD, Conrad RF, Keeler AG, Opaluch JJ, Peterson CH, Piehler MF, Powers SP, Smyth AR (2012) Economic valuation of ecosystem services provided by oyster reefs. Bioscience 62:900-909

Gutiérrez JL, Jones CG, Strayer DL, Iribarne OO (2003) Mollusks as ecosystem engineers: the role of shell production in aquatic habitats. Oikos 101(1):79-90

Harding JM, Mann R (2001) Oyster reefs as fish habitat: opportunistic use of restored reefs by transient fishes. J Shellfish Res 20(3):951-959

Harding JM, Mann R (2003) Influence of habitat on diet and distribution of striped bass (Morone saxatilis) in a temperate estuary. Bull Mar Sci 72:841-851

Humphries AT, La Peyre MK (2015) Oyster reef restoration supports increased nekton biomass and potential commercial fishery value. PeerJ 3:e1111. https://doi.org/10.7717/peerj.1111

Humphries AT, La Peyre MK, Decossas GA (2011) The effect of structural complexity, prey density, and "predator-free space" on prey survivorship at created oyster reef Mesocosms. PLoS One 6:e28339

Jones CG, Lawton JH, Shachak M (1994) Organisms as ecosystem engineers. Oikos 69:373-386

Kellogg ML, Cornwell JC, Owens MS, Paynter KT (2013) Denitrification and nutrient assimilation on a restored oyster reef. Mar Ecol Prog Ser 480:1-19. https://doi.org/10.3354/meps10331

Kent FEA, Gray MJ, Last KS, Sanderson WG (2016) Horse mussel reef ecosystem services: evidence for a whelk nursery habitat supporting a shellfishery. Int J Biodivers Sci Ecosyst Serv Manag 12:172-180. https://doi.org/10.1080/21513732.2016.1188330

Kent FEA, Mair JM, Newton J, Lindenbaum C, Porter JS, Sanderson WG (2017) Commercially important species associated with horse mussel (Modiolus modiolus) biogenic reefs: a priority habitat for nature conservation and fisheries benefits. Mar Pollut Bull 118:71-78. https://doi. org/10.1016/j.marpolbul.2017.02.051

Kesler KE (2015) Influence of the biotic and structural components of Crassostrea virginca on the oyster reef community. Doctor of Philosophy, University of Maryland, $162 \mathrm{pp}$

Levin PS, Stunz GW (2005) Habitat triage for exploited fishes: can we identify essential "essential fish habitat?". Estuar Coast Shelf Sci 64(1):70-78. https://doi.org/10.1016/j.ecss.2005.02.007

Lorenzen K (2000) Allometry of natural mortality as a basis for assessing optimal release size in fish-stocking programmes. Can J Fish Aquat Sci 57:2374-2381

Minns CK, Randall RG, Smokorowski KE, Clarke KD, Vélez-Espino A, Gregory RS, Courtenay S, LeBlanc P (2011) Direct and indirect estimates of the productive capacity of fish habitat under Canada's Policy for the Management of Fish Habitat: where have we been, where are we now, and where are we going? Can J Fish Aquat Sci 68(12):2204-2227. https://doi.org/10.1139/ f2011-130

Moebius K (1883) The oyster and oyster-culture. Report of commissioner of fish and fisheries, pp 683-747

NOAA (1977) Habitat equivalency analysis: an overview, policy and technical paper series, no. 95-1, damage assessment and restoration program. National Oceanographic and Atmospheric Administration, Silver Spring, MD, USA

Ogburn DM, White I, McPhee DM (2007) The disappearance of oyster reefs from eastern Australian estuaries - impact of colonial settlement or mudworm invasion? Coast Manag 35:271-287

OPA (1990) Oil Pollution Act available at https://www.congress.gov/bill/101st-congress/ house-bill/1465

Petersen J, Holmer M, Termansen M, Hasler B (2019) Nutrient extraction through bivalves. In: Smaal A, Ferreira JG, Grant J, Petersen JK, Strand O (eds) Goods and services of marine bivalves. Springer, Cham, pp 143-177

Peterson CH, Summerson HC, Thomson E, Lenihan HS, Grabowski J, Manning L, Micheli F, Johnson G (2000) Synthesis of linkages between benthic and fish communities as a key to protecting essential fish habitat. Bull Mar Sci 66(3):759-774

Peterson CH, Grabowski JH, Powers SP (2003) Estimated enhancement of fish production resulting from restoring oyster habitat: quantitative valuation. Mar Ecol Prog Ser 264:249-264

Philpots JR (1890) Oysters and all about them. John Richardson \& Co, London/Leicester

Pierson KJ, Eggleston DB (2014) Response of estuarine fish to large-scale oyster reef restoration. Trans Am Fish Soc 143:273-288 
Pikitch EK, Santora C, Babcock EA, Bakun A, Bonfil R, Conover DO, Dayton P, Doukakis P, Fluharty D, Heneman B, Houde ED, Link J, Livingston PA, Mangel M, McAllister MK, Pope J, Sainsbury KJ (2004) Ecosystem-based fishery management. Science 305:346-347

Rick TC, Erlandson JM (2009) Coastal exploitation. Science 952:325-326

Riesen W, Reise K (1982) Macrobenthos of the subtidal Wadden Sea: revisited after 55 years. Helgoländer Meeresun 35:409-423

Rosenberg AA, Restrepo VR (1994) Uncertainty and risk evaluation in stock assessment advice for U.S. Marine Fisheries. Can J Fish Aquat Sci 51:2715-2720

Saville-Kent W (1894) Fish and fisheries of Western Australia, from the registrar generals western Australian year-book 1893-4. Commissioner of Fisheries to the West Australian Government

Smaal A, van Duren L (2019) Bivalve aquaculture carrying capacity: concepts and assessment tools. In: Smaal A, Ferreira JG, Grant J, Petersen JK, Strand O (eds) Goods and services of marine bivalves. Springer, Cham, pp 451-483

Stenzel HB (1971) Oysters. In: Moore RC (ed) Treatise on invertebrate paleontology, part N. University of Kansas Press, Kansas, pp 953-1224

Stunz GW, Minello TJ, Rozas LP (2010) Relative value of oyster reef as habitat for estuarine nekton in Galveston Bay, Texas. Mar Ecol Prog Ser 406:147-159

Todorova V, Micu D, Klisurov L (2009) Unique oyster reefs discovered in the Bulgarian Black Sea. Comptes rendus de l'Acad'emie bulgare des Sciences 62(7):871-874

Walles B, Mann R, Ysebaert T, Troost K, Herman PMJ, Smaal AC (2015) Demography of the ecosystem engineer Crassostrea gigas, related to vertical reef accretion and reef persistence. Estuar Coast Shelf Sci 154:224-233

Watson RA, Coles RG, Lee Long W (1993) Simulation estimates of annual yield and landed value for commercial penaeid prawns from a tropical seagrass habitat, northern Queensland, Australia. Aust J Mar Freshwat Res 44:211-219

Ysebaert T, Hancock B, Walles B (2019) Habitat modification and coastal protection by ecosystem-engineering reef-building bivalves. In: Smaal A, Ferreira JG, Grant J, Petersen JK, Strand O (eds) Goods and services of marine bivalves. Springer, Cham, pp 253-273

zu Ermgassen PSE, Spalding MD, Blake BD, Coen LD, Dumbauld B, Geiger S, Grabowski JH, Grizzle R, Luckenbach M, McGraw K, Rodney W, Ruesink JL, Powers SP, Brumbaugh R (2012) Historical ecology with real numbers: past and present extent and biomass of an imperiled estuarine ecosystem. Proc R Soc B 279:3393-3400. https://doi.org/10.1098/rspb.2012.0313

zu Ermgassen P, Spalding M, Allison A (2013) The native oyster: Britain's forgotten treasure. Br Wildl 2013:317-324

zu Ermgassen PSE, Grabowski JH, Gair JR, Powers SP (2016a) Quantifying fish and mobile invertebrate production from a threatened nursery habitat. J Appl Ecol 53:596-606. https://doi. org/10.1111/1365-2664.12576

zu Ermgassen P, Hancock B, DeAngelis B, Greene J, Schuster E, Spalding M, Brumbaugh R (2016b) Setting objectives for oyster habitat restoration using ecosystem services: a manager's guide. The Nature Conservancy, Arlington, 76pp

zu Ermgassen PSE, Grabowski JH, Gair JR, Powers SP (2018) Corrigendum. J Appl Ecol. https:// doi.org/10.1111/1365-2664.13143

Open Access This chapter is licensed under the terms of the Creative Commons Attribution 4.0 International License (http://creativecommons.org/licenses/by/4.0/), which permits use, sharing, adaptation, distribution and reproduction in any medium or format, as long as you give appropriate credit to the original author(s) and the source, provide a link to the Creative Commons license and indicate if changes were made.

The images or other third party material in this chapter are included in the chapter's Creative Commons license, unless indicated otherwise in a credit line to the material. If material is not included in the chapter's Creative Commons license and your intended use is not permitted by statutory regulation or exceeds the permitted use, you will need to obtain permission directly from the copyright holder. 